\title{
Correction to: Balloon occluded TACE (B-TACE) vs DEM-TACE for HCC: a single center retrospective case control study
}

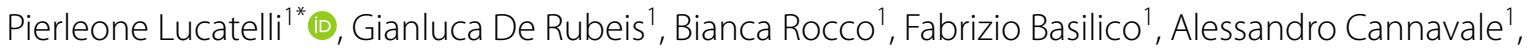
Aurelio Abbatecola², Pier Giorgio Nardis ${ }^{1}$, Mario Corona ${ }^{1}$, Stefania Brozzetti ${ }^{3}$, Carlo Catalano ${ }^{1}$ and Mario Bezzi ${ }^{1}$

\section{Correction to: BMC Gastroenterol (2021) 21:51} https://doi.org/10.1186/s12876-021-01631-w Following publication of the original article [1], the authors identified an error in the author name of Stefania Brozzetti.

- The incorrect author name is: Stefania Brozetti.

- The correct author name is: Stefania Brozzetti.

The author group has been updated above and the original article [1] has been corrected.

\section{Author details}

'Vascular and Interventional Radiology Unit, Department of Diagnostic Service, Sapienza University of Rome, Viale Regina Elena 324, 00161 Rome, Italy. ${ }^{2}$ Gastroenterology Division, Department of Clinical Medicine, Sapienza University of Rome, Rome, Italy. ${ }^{3}$ Pietro Valdoni Surgery Department, Sapienza" University of Rome, Rome, Italy.

Published online: 09 July 2021

\section{Reference}

1. Lucatelli P, De Rubeis G, Rocco B, et al. Balloon occluded TACE (B-TACE) vs DEM-TACE for HCC: a single center retrospective case control study. BMC Gastroenterol. 2021;21:51. https://doi.org/10.1186/s12876-021-01631-w.

\section{Publisher's Note}

Springer Nature remains neutral with regard to jurisdictional claims in published maps and institutional affiliations.

The original article can be found online at https://doi.org/10.1186/s12876021-01631-w.

*Correspondence: pierleone.lucatelli@gmail.com

${ }^{1}$ Vascular and Interventional Radiology Unit, Department of Diagnostic

Service, Sapienza University of Rome, Viale Regina Elena 324, 00161 Rome,

Italy

Full list of author information is available at the end of the article

(c) The Author(s) 2021. This article is licensed under a Creative Commons Attribution 4.0 International License, which permits use, sharing, adaptation, distribution and reproduction in any medium or format, as long as you give appropriate credit to the original author(s) and the source, provide a link to the Creative Commons licence, and indicate if changes were made. The images or other third party material in this article are included in the article's Creative Commons licence, unless indicated otherwise in a credit line to the material. If material is not included in the article's Creative Commons licence and your intended use is not permitted by statutory regulation or exceeds the permitted use, you will need to obtain permission directly from the copyright holder. To view a copy of this licence, visit http://creativecommons.org/licenses/by/4.0/. The Creative Commons Public Domain Dedication waiver (http://creativecommons.org/publicdomain/zero/1.0/) applies to the data made available in this article, unless otherwise stated in a credit line to the data. 